\title{
HIGH STAKES: HOW TO DEFINE "DISABILITY" IN MEDICAL MARIJUANA STATES IN LIGHT OF THE AMERICANS WITH DISABILITIES ACT, CANADIAN LAW, AND THE IMPACT ON EMPLOYERS
}

\author{
Lindsey M. Tucker
}

INTRODUCTION

Since California first blazed the trail to legalize medical marijuana by voter referendum in 1996, fourteen states and the District of Columbia have followed suit in an attempt to relieve patients from their torn decision between medicating themselves with medical marijuana and committing a crime. $^{1}$ The states have done this by removing or lowering state criminalization associated with marijuana possession and use for medical purposes. ${ }^{2}$ Although states are rolling in the direction of legalizing medical marijuana, federal law is clear that marijuana is still an illegal Schedule I controlled drug with no recognized medical value. ${ }^{3}$ In line with federal law, the Americans with Disabilities Act precludes the recognition of a marijuana addiction accompanied by current marijuana use to qualify as a disability under the Act. ${ }^{4}$ While an addiction to marijuana is not a disability in the United States, recent Canadian case law concluded the opposite. ${ }^{5}$ Neither our northern neighbor's position nor a minority of states' medical marijuana laws should make the rest of the United States second guess the legality of disability discrimination laws. ${ }^{6}$

Although medical marijuana laws provide a compassionate ${ }^{7}$ answer for treatment-related issues in patients' lives, they leave questions open as to the impact on other realms of life, like employment. ${ }^{8}$ In Canada, medical

* Doctor of Jurisprudence, Indiana University School of Law-Indianapolis, May 2011. I would like to thank my husband Ryan, my parents Doug and Linda Nies, and my extended family and friends for their support. I would also like to thank Professor Steven Miller for his research guidance and encouragement.

1. Active State Medical Marijuana Programs, NAT'L ORG. FOR THE REFoRM OF MARIJUANA LAWS, http://norml.org/index.cfm?Group_ID=3391 (last updated Dec. 1, 2004).

2. Id.

3. 21 U.S.C. $\$ 812(2000)$.

4. Facts About the Americans with Disabilities Act, U.S. EQUAL EMP'T OPPORTUNITY COMM'N, http://www.eeoc.gov/facts/fs-ada.html (last modified Sept. 9, 2008).

5. See Rio Tinto Alcan Primary Metal v. C.A.W.-Canada, Local 2301 (2008), 180 L.A.C. 4 th 1 (Can. B.C.).

6. See infra Parts III, IV.

7. See infra Part I.B.2 (discussing the term "compassion" in the medical marijuana context).

8. See infra Part I.B.2 (discussing state case law regarding medical marijuana). 
marijuana laws have a direct effect on employers. ${ }^{9}$ Canadian law requires employers to reasonably accommodate and excuse drug test provisions for medical marijuana users. ${ }^{10}$ Different treatments between the U.S. government and the Canadian government on medical marijuana users' employment can be harmonized. $^{11}$ In the face of studies showing both the short- and long-term physical and cognitive effects of marijuana, employers have much at stake. ${ }^{12}$ For example, employers must consider the impact upon employees, customers, and other stakeholders when making decisions for the future of their business regarding the use of medical marijuana in the workplace. ${ }^{13}$ With safety and cost concerns, public policy within the United States is on the side of employers promoting drug-free work environments. $^{14}$

This Note will not focus on the debate over legalization of marijuana or medical marijuana. Instead, the discussion will compare the effect that current medical marijuana laws have on established disability discrimination laws in the employment arenas of the United States and Canada. The analysis of U.S. statutory and case law will be limited to California, as the medical marijuana vanguard; Oregon, with much ongoing activity regarding its statutory and case law; and Michigan, as an Indiana neighbor and one of the most recent states to enact medical marijuana legislation.

Part I of this Note discusses the definition of marijuana and its purposes. Part I also explores the evolution of medical marijuana laws in the United States and Canada. Part II assesses the current statutory and case law regarding disability discrimination in the employment context in both the United States and Canada. Part III discusses the operational, economic, and public policy effects that medical marijuana has on the workplace. Part IV discusses how U.S. and Canadian law can be harmonized. Finally, Part V recommends that states protect an employer's right to enforce drug-free workplaces, draft medical marijuana acts cautiously, and pass bills to clarify existing medical marijuana acts. Additionally, Part V recommends that courts continue to read medical marijuana laws in light of their purpose of decriminalization of the use of medical marijuana, and that U.S. federal and state governments come to a uniform decision on how medical marijuana laws impact employment laws.

9. See Rio Tinto, 180 L.A.C. 4th 1; N. Am. Constr. Grp. Inc. v. Alberta, 2003 ABQB 755 (Can. Alta.); Geldreich v. Whisper Corwood LP, 2009 BCHRT 178 (Can. B.C.).

10. See Rio Tinto, 180 L.A.C. 4th 1; N. Am. Constr., 2003 ABQB 755; Geldreich, 2009 BCHRT 178.

11. See infra Part IV.

12. See infra Part III.

13. Id.

14. Id. 


\section{BACKGROUND ON MEDICAL MARIJUANA, LEGALIZATION OF MEDICAL MARIJUANA, AND THE U.S. AND CANADIAN EMPLOYMENT LAW SYSTEMS}

\section{A. Medical Marijuana}

Cannabis sativa is the plant more commonly known as marijuana. ${ }^{15}$ Marijuana has two recognized uses: recreational and medical. ${ }^{16}$ These two uses may result in different legal consequences. ${ }^{17}$ The use of marijuana for recreational purposes is illegal throughout most of the world including the United States and Canada. ${ }^{18}$ However, the use of marijuana for medicinal purposes dates back to 2700 B.C. ${ }^{19}$ Marijuana has been "promoted for a variety of conditions based on its putative analgesic, sedative, antiinflammatory, antispasmodic, antiasthmatic and anticonvulsant properties." ${ }^{20}$ Marijuana's use has been recognized for the treatment of acquired immune deficiency syndrome or AIDS, cancer and chemotherapyinduced nausea and vomiting, glaucoma, multiple sclerosis, spasticity, and epilepsy, ${ }^{21}$ as well as chronic pain, arthritis, and migraines.

While there are recognized medical benefits associated with the use of marijuana, there are also well-known harms, regardless of its use for medical or recreational purposes. Marijuana can either be smoked or swallowed; either form of consumption has intoxicating effects and potential harmful health consequences, such as euphoria, slowed thinking and reaction time, confusion, impaired balance and coordination, cough, frequent respiratory infections, impaired memory and learning, increased heart rate, anxiety, panic attacks, tolerance, and addiction. ${ }^{23}$ In the 1930s, the United States staged a "war on marijuana" by associating fear with marijuana use through stories and movies produced by the Federal Bureau of Narcotics entitled "Marijuana-Assassin of Youth", "Marijuana-Sex-

15. Peter J. Cohen, Medical Marijuana: The Conflict Between Scientific Evidence and Political Ideology, 2009 UTAH L. REv. 35, 37 (2009).

16. Id. at 39-40.

17. See infra Parts I.B-C.

18. Cohen, supra note 15 , at 37 .

19. Id. at 35 .

20. Report 10 of the Council on Scientific Affairs (1-97), AMERICAN MEDICAL Association, http://www.ama-assn.org/ama/no-index/about-ama/13580.shtml (last visited Apr. 10, 2011).

21. Id.

22. Cal. Health \& Safety Code ANN. $§ 11362.5$ (A) (West 1996).

23. Commonly Abused Drugs, Nat'L InST. on Drug ABuSE, NAT'L Insts. OF Health, http://www.nida.nih.gov/DrugPages/DrugsofAbuse.html (last visited Apr. 10, 2011). 
Crazy Drug Menace", and "Reefer Madness."24 Through these press tools, the bureau conveyed the message that "casual marijuana use ... [would] lead swiftly to murder, rape, prostitution, addiction, madness, and death., 25 These portrayals succeeded in characterizing marijuana as a monster, and the harmful effects and fears associated with the drug masked its potential health benefits. ${ }^{26}$

\section{B. Legalization of Medical Marijuana in the United States}

The United States is a federation consisting of a centralized, federal government and fifty states each with their own state and local governments. ${ }^{27}$ U.S. labor and employment laws exist both at federal and state levels. $^{28}$ These federal, state, and local discrimination laws may conflict with each other. ${ }^{29}$ Where a conflict exists, the law offering the greatest protection for employees should govern. ${ }^{30}$

\section{Federal Law}

In 1937, the United States passed the 1937 Marijuana Tax Act, the first federal prohibition of marijuana. ${ }^{31}$ During congressional hearings, counsel for the American Medical Association protested the proposed act, citing the potential for future medical benefits of marijuana. ${ }^{32}$.In spite of those protests, Congress passed the Act on October $1,1937 .{ }^{33}$ Although not explicitly, the Act constructively outlawed marijuana through heavy administrative burdens and taxation on the grower, distributor, seller, and buyer. $^{34}$ Soon after the Act's passing, most states passed laws making it a felony to sell or use marijuana.

Currently, marijuana is listed as a Schedule I drug under the federal Uniform Controlled Substance Act (CSA). ${ }^{36}$ A Schedule I drug is a

24. Kara Godbehere Goodwin, Note, Is the End of the War in Sight: An Analysis of Canada's Decriminalization of Marijuana and the Implications for the United States "War on Drugs", 22 BufF. PUB. INT. L.J. 199, 202 (2003).

25. Id.

26. Id.

27. INTERNATIONAL LABOR AND EMPloyment LAW 235 (Philip M. Berkowitz et al. eds., 2d ed., vol. II 2008).

28. Id. at 247 .

29. Id.

30. Id. at $247-48$.

31. Abbie Crites-Leoni, Medicinal Use of Marijuana: Is the Debate a Smoke Screen for Movement Toward Legalization?, 19 J. LEGAL MED. 273, 275 (1998).

32. Goodwin, supra note 24.

33. Id.

34. Id.

35. Id. at $202-03$.

36. 21 U.S.C. $\S 812(2000)$. 
substance that "has a high potential for abuse[,] . . . no currently accepted medical use in treatment in the United States[, and] . . a lack of accepted safety for use of the drug or other substance under medical supervision., 37 Concurring with marijuana's characterization as a Schedule I drug, the United States Food and Drug Administration (FDA) maintains that marijuana has harmful effects and is not an approved pharmaceutical. ${ }^{38}$ However, contrary state laws frustrate "the efforts to ensure that medications undergo the rigorous scientific scrutiny of the FDA approval process and are proven safe and effective under the standards of the [Food, Drug and Cosmetics] Act.",39

In 2005, the United States Supreme Court in Gonzales v. Raich upheld the enforcement of the CSA against using and distributing medical marijuana even though their actions were legal under state law. ${ }^{40}$ This permitted the United States Drug Enforcement Administration (DEA) to continue marijuana raids, even if those raids targeted individuals using or selling medical marijuana in compliance with state law. ${ }^{41}$

However, Gonzales is not the final say on DEA enforcement of the CSA in medical marijuana states. When President Barack Obama took office on January 20,2009, he brought a different view than the previous administration on the enforcement of the CSA, which insisted on enforcing federal drug laws regardless of state laws. ${ }^{42}$ On October 19, 2009, the U.S. Department of Justice, under President Obama's direction, issued a memorandum clarifying investigations and prosecutions in states with medical marijuana laws. ${ }^{43}$ When marijuana is used or provided in accordance with state law, the memorandum states that "it is not a good use of federal manpower to prosecute those who are without a doubt in compliance with state law." ${ }^{44}$ Rather, the memorandum urges that federal resources be used on the prosecution of people distributing and trafficking drugs and those using medical marijuana as a cover for other illegal conduct. $^{45}$

37. Id. $\S 812(\mathrm{~b})(1)$.

38. Inter-Agency Advisory Regarding Claims that Smoked Marijuana is a Medicine, U.S. FOOD AND DRUG ADMIN. (Apr. 20, 2006), http://www.fda.gov/NewsEvents/Newsroom/ PressAnnouncements/2006/ucm108643.htm.

39. Id.

40. See Gonzales v. Raich, 545 U.S. 1, 2 (2005).

41. See Feds: No More Arrests for Pot Smoking Patients, MSNBC (Oct. 19, 2009, 11:02:03 AM), http://www.msnbc.msn.com/id/33376482/ns/health/?GT1=43001.

42. Id.

43. Id.

44. Id.

45. Id. 


\section{State Law}

Despite the federal government's position on medical marijuana, fifteen states, including Alaska, Arizona, California, Colorado, Hawaii, Maine, Michigan, Montana, Nevada, New Jersey, New Mexico, Oregon, Rhode Island, Vermont, and Washington, as well as the District of Columbia, have legalized medical marijuana through either state legislatures or voter referendums through compassionate use acts. ${ }^{46}$ Maryland also has a compassionate use act but instead of complete legalization, the state criminal penalty has been lowered to a one-hundred dollar fine. $^{47}$

California was the first state to enact medical marijuana legislation. ${ }^{48}$ The Compassionate Use Act of 1996 decriminalized the usage and sale of medical marijuana in California. ${ }^{49}$ The Act provides that its purpose is " $[t] 0$ ensure that patients and their primary caregivers who obtain and use marijuana for medical purposes upon the recommendation of a physician are not subject to criminal prosecution or sanction." though the Act safeguards a patient's right to use marijuana for medical purposes, the Act is not to "be construed to supersede legislation prohibiting persons from engaging in conduct that endangers others.",51

Oregon passed the Oregon Medical Marijuana Act in 1999. It states:

[A] person engaged in . . . medical use of marijuana is excepted from the criminal laws of the state for possession, delivery or production of marijuana, aiding and abetting another in the possession, delivery or production of

46. Alaska Stat. $\$ \S 17.37 .030-17.37 .040$ (1999); Cal. Health \& SafeTy Code ANN. $\S 11362.5$ (West 1996); Colo. Rev. Stat. ANN. § 18-18-406.3 (West 2001); HaW. Rev. Stat. ANN. § 329-122 (West 2000); 2008 Me. Legis. Serv. 631 (West); Mrch. CoMP. LaWs ANN. §§ 333.26424-333.26428 (West 2008); MONT. CODE ANN. $\S \S 50-46-201,50-46-205$ (2004); Nev. Rev. Stat. ANN. § 453A.200 (West 2000); N.J. STAT. ANN. § 24:6I (West 2010); N.M. STAT. ANN. § 26-2B-4 (West 2007); OR. Rev. Stat. ANN. $§ \$ 475.316,475.340$ (West 1999); R.I. GEN. LAWS ANN. § 21-28.6-4 (West 2006); VT. STAT. ANN. tit. 18, § 4474b (West 2004); WASH. REV. CODE ANN. $\S \S 69.51$ A.005-69.51A.060 (West 1999); 2010 Ballot Propositions and Judicial Performance Review, ARIZ. OfFICE OF THE SEC'Y OF STATE, ARIZ. DEP'T OF STATE, http://www.azsos.gov/election/2010/info/PubPamphlet/english/Prop 203.htm (last visited Apr. 10, 2011); A Bill, 18-622, in the Council of the District of Columbia, NAT'L ORG. FOR THE REFORM OF MARIJUANA LAWS, http://norml.org/pdf_files/AINS_as_passed_at_COW_4_20_2010.pdf (last visited Apr. 10, 2011); Ashley Southall, Washington, D.C., Approves Medical Use of Marijuana, N.Y. TIMES (May 4, 2010), http://www.nytimes.com/ 2010/05/05/us/05marijuana.html.

47. Active State Medical Marijuana Programs, supra note 1.

48. Id.

49. Cal. HEalth \& SAfETY CODE ANN. $\$ 11362.5$ (West 1996).

50. Id.

51. Id. 
marijuana or any other criminal offense in which possession, delivery or production of marijuana is an element. $^{52}$

Michigan passed its Medical Marihuana Act in 2008 via voter referendum. ${ }^{33}$ Michigan's law is similar to California's and Oregon's, but some striking differences exist. ${ }^{54}$ Regarding protections for medical marijuana users, Michigan's law states:

A qualifying patient ... shall not be subject to arrest, prosecution, or penalty in any manner, or denied any right or privilege, including but not limited to civil penalty or disciplinary action by a business or occupational or professional licensing board or bureau, for the medical use of marihuana in accordance with this act. ${ }^{55}$

However, the exceptions and scope of Michigan's law create a conflict regarding its legal protections. For example, Michigan's law does not require an employer to accommodate the use of medical marijuana by its employees and even goes as far as to itemize specific settings in which the influence of marijuana is not allowed: ${ }^{56}$

(b) This act shall not permit any person to do any of the following: (1) Undertake any task under the influence of marihuana, when doing so would constitute negligence or professional malpractice. (2) Possess marihuana, or otherwise engage in the medical use of marihuana: $(A)$ in a school bus; (B) on the grounds of any preschool or primary or secondary school; or (C) in any correctional facility. (3) Smoke marihuana: (A) on any form of public transportation; or (B) in any public place. (4) Operate, navigate, or be in actual physical control of any motor vehicle, aircraft, or motorboat while under the influence of

52. OR. Rev. Stat. ANN. § 475.309(1) (West 1999).

53. Active State Medical Marijuana Programs, supra note 1. Additionally, the term "marijuana" will be primarily used in this Note. However, in order to accurately cite authorities, "marijuana" and "marihuana" will be used interchangeably in accordance with the cited authority's use of the term.

54. Compare Mich. CoMP. Laws ANN. §§ 333.26424-333.26428 (West 2008) with CAL. HEAlTH \& SAFETY CODE ANN. $§ 11362.5$ (West 1996) and OR. Rev. STAT. ANN. $\S \S 475.316$, 475.340 (West 1999).

55. See Mich. CoMP. LAwS ANN. $§ 333.26424$ (West 2008).

56. Id. $\S \S 333.26424-333.26428$. 
marihuana ... ${ }^{57}$ (c) Nothing in this act shall be construed to require: (2) An employer to accommodate the ingestion of marihuana in any workplace or any employee working while under the influence of marihuana. ${ }^{58}$

If history teaches anything, it may be that legal challenges to the application and interpretation of Michigan's law are inevitable, as has been the case with older acts such as California's and Oregon's compassionate use acts. ${ }^{59}$ Additionally, ten states have pending legislation or ballot measures to legalize medical marijuana, including Alabama, Connecticut, Delaware, Idaho, Illinois, Maryland, Massachusetts, New Hampshire, New York, and North Carolina. ${ }^{60}$

\section{Legalization of Medical Marijuana in Canada}

Canada is a federation consisting of ten provinces and three territories. ${ }^{61}$ Canada has two levels of government: federal and provincial. $^{62}$ All Canadian jurisdictions prohibit discrimination against physical or mental disability. ${ }^{63}$ The Canadian Human Rights Act governs such discriminatory practices in employment. ${ }^{64}$

The 1923 Opium and Narcotic Drug Act made marijuana illegal. ${ }^{65}$ Similar to the U.S. current classification, marijuana was considered a Schedule I drug in Canada. ${ }^{66}$ After a period of long, undulated debate and research as to whether marijuana should be approached on a criminal or health level, marijuana was reclassified as a Schedule II drug with a lower, misdemeanor-like criminal penalty for possession by the passage of the Canadian Controlled Drugs and Substances Act in May of 1997. ${ }^{67}$

An Ontario case paved the way for the legalization of medical marijuana. ${ }^{68}$ In $R . v$. Parker, the Canadian courts signaled the legislature to step in and legalize marijuana for medical purposes. ${ }^{69}$ The defendant

57. Id. $\S 333.26427$.

58. $I d$.

59. See infra Part II.A.

60. 10 States with Pending Legislation to Legalize Medical Marijuana, ProCon.ORG, http://medicalmarijuana.procon.org/viewresource.asp?resourcelD=002481 (last updated Apr. 6, 2011, 10:40:13 AM PST).

61. INTERNATIONAL LABOR AND EMPLOYMENT LAW, supra note 27, at 53.

62. $I d$.

63. Id. at 69.

64. See Canadian Human Rights Act, R.S.C. 1985, c. H-6.

65. Goodwin, supra note 24, at 206.

66. Id. at 208.

67. Id. at 207-08.

68. See R. v. Parker (2000), 49 O.R. 3d 481 (Can. Ont. C.A.).

69. See id. paras. 207, 210. 
suffered from epilepsy and used marijuana to reduce the frequency and intensity of seizures. ${ }^{70}$ The defendant's residence was searched and he was charged with possession of marijuana in violation of the Controlled Drugs and Substance Act. ${ }^{71}$ The court held that by charging the defendant with possession of marijuana, the criminal imposition impaired his rights under the Canadian Charter of Rights and Freedom to life, liberty and security of person. $^{72}$ A medical exception was read into the Controlled Drugs and Substance Act for the defendant until the legislature enacted medical marijuana laws. ${ }^{73}$ Once enacted, Canada's Marihuana Medical Access Regulations state that "[t]he holder of an authorization to possess is authorized to possess dried marihuana, in accordance with the authorization, for the medical purpose of the holder.",74

In June of 2001, responding to the decision in $R v$. Parker, the Canadian Controlled Drugs and Substances Act was amended, in connection with the Marihuana Medical Access Regulations, to "allow possession and purchase of marijuana for legitimate medical needs." ${ }^{75}$ The Marihuana Medical Access Regulations authorize Health Canada, a department of the Canadian federal government in charge of "helping Canadians maintain and improve their health, while respecting individual choices and circumstances," ${ }^{, 76}$ to regulate medical marijuana use and distribution, which is available to those suffering from "grave and debilitating illnesses." $" 77$ Canada makes the position clear that legalization only applies to certain authorized medical uses. ${ }^{78}$ Further, marijuana is still considered a controlled substance in Canada although its controlled substance classification is different than in the United States. ${ }^{79}$

70. Id. para. 3 .

71. Id.

72. Id. para. 152 .

73. Id. para. 210 .

74. Marihuana Medical Access Regulations, SOR/2001-227 (Can.).

75. Id.

76. About Health Canada, HEALTH CANADA, http://www.hc-sc.gc.ca/ahc-asc/indexeng.php (last modified Feb. 16, 2011).

77. Law Enforcement Issues-Medical Use of Marihuana, HEALTH CANADA, http://www.hc-sc.gc.ca/dhp-mps/marihuana/law-loi/index-eng.php (last modified Sept. 15, 2010).

78. $I d$.

79. Id. 


\section{CURRENT U.S. AND CANADIAN DISABILITY DISCRIMINATION LAWS AND THE EFFECT OF MEDICAL MARIJUANA USE ON THOSE LAWS}

\section{A. U.S. Law}

The Americans with Disabilities Act (ADA) is a U.S. federal law protecting employees from discrimination on the basis of disability. ${ }^{80}$ Specifically, disability discrimination usually falls under the category of "disparate treatment cases," which is an "intentional discrimination based on illegal or protected criteria." ${ }^{, 81}$ Title I of the ADA applies to private employers, state and local governments, employment agencies and labor unions, provided that such employers employ fifteen or more employees. ${ }^{82}$

Title I prohibits employers from discriminating against qualified individuals with disabilities in "job application procedures, the hiring, advancement, or discharge of employees, employee compensation, job training, and other terms, conditions, and privileges of employment." ${ }^{83}$ The ADA defines a qualified individual as "an individual who, with or without reasonable accommodation, can perform the essential functions of the employment position that such individual holds or desires." ${ }^{84}$ The ADA provides that "[a]n individual with a disability is a person who: [h]as a physical or mental impairment that substantially limits one or more major life activities; [h] as a record of such an impairment; or [i]s regarded as having such an impairment." 85

Under the ADA, "[a]n employer is required to make a reasonable accommodation to the known disability of a qualified applicant or employee if it would not impose an 'undue hardship' on the operation of the employer's business." ${ }^{86}$ An undue hardship is "an action requiring significant difficulty or expense when considered in light of such factors as an employer's size, financial resources, and the nature and structure of its operation. 87

The ADA does not protect "employees and applicants currently engaging in the illegal use of drugs ... when an employer acts on the basis of such use." ${ }^{88}$ Additionally, the ADA's restrictions on medical

80. INTERNATIONAL LABOR AND EMPLOYMENT LAW, supra note 27, at 248.

81. Id.

82. 42 U.S.C. $\S 12111(2010)$.

83. Id. $\S 12112$.

84. Id. $\S 12111$.

85. Facts About the Americans with Disabilities Act, supra note 4.

86. Id.

87. Id.

88. Id. 
examinations do not apply to illegal drug tests. ${ }^{89}$ Employees who use illegal drugs can also be held to the same standard as other employees. ${ }^{90}$

The Americans with Disabilities Act Amendments Act of 2008 took effect on January 1, 2009. ${ }^{91}$ The primary goal of this amendment was to broaden the scope of coverage for individuals to the maximum extent of the terms of the ADA. ${ }^{92}$ The amendment keeps the basic definition of disability and alters or expands the definitions of "substantially limits" and "major life activities." It is yet to be determined whether the amendment leaves the door open to protections for users of medical marijuana.

In Ross v. RagingWire Telecommunications, Inc., Gary Ross sued his former employer under the California Fair Employment and Housing Act (FEHA) because Ross was fired after he failed a pre-employment drug test due to his use of medical marijuana pursuant to the California Compassionate Use Act. ${ }^{94}$ Ross qualified as having a physical disability under FEHA due to strain and muscle spasms in his back; as such, Ross received disability benefits. ${ }^{95}$ Ross' doctor recommended Ross use medical marijuana to alleviate his physical symptoms prior to his employment at RagingWire. $^{96}$ Ross had to take a pre-employment drug test and was up front with both the testing facility and his employer regarding his doctor's medical marijuana recommendation. ${ }^{97}$ Despite the fact that Ross used marijuana under the recommendation of his doctor, Ross was terminated for testing positive for marijuana. ${ }^{98}$ Based on these facts, the court held that the purpose of the Compassionate Use Act was to eliminate criminalization of medical marijuana and does not provide a remedy to Ross for the failure of an employer to accommodate the employee's use of marijuana under the FEHA. 99

Justice Kennard, in dissent, did not believe that the California Compassionate Use Act was intended to allow an "employer [to] fire an employee for such marijuana use even when it occurs during off-duty hours, does not affect the employee's job performance, does not impair the employer's legitimate business interests, and provides the only effective

89. Id.

90. Id.

91. Notice Concerning the Americans with Disabilities Act (ADA) Amendments Act of 2008, U.S. EQUAL EMP'T OPPORTUNITY COMM'N, http://www.eeoc.gov/ada/amendments notice.html (last visited Apr. 10, 2011).

92. Id.

93. Id.

94. Ross v. RagingWire Telecommunications, Inc., 174 P.3d 200, 202 (Cal. 2008).

95. Id. at 203 .

96. Id.

97. Id.

98. Id.

99. Id. at 204-05. 
relief for the employee's chronic pain and muscle spasms."100 Justice Kennard further argued that when voters gave patients access to medical marijuana, they did not intend for patients to be excluded from employment. ${ }^{101}$ Justice Kennard would hold that unless an employer shows that an employee's off-duty use of doctor-approved medical marijuana "is likely to impair the employer's business operations in some way," the employee's termination is a result of disability discrimination.

When interpreting the Compassionate Use Act in light of the facts of this case, Justice Kennard maintained that "[c]ourts must construe statutes to effectuate the purpose of the law." 103 Subsection B of the Act provides that "patients and their primary caregivers who obtain and use marijuana for medical purposes upon the recommendation of a physician are not subject to criminal prosecution or sanction." 104 While the majority focused on the Act's purpose of removing criminalization at the state level, Justice Kennard emphasized the inclusion of "sanction" in the statutory provision. ${ }^{105}$ Specifically, he equated termination of employment as a sanction against marijuana users merely acting pursuant to the Act. ${ }^{106}$ Justice Kennard summarized the majority's holding as leaving two choices for patients seeking to relieve their symptoms with marijuana: "continue [to receive] the benefits of marijuana use ... and become unemployed, giving up what may be their only source of income, or continue in their employment, discontinue marijuana treatment, and try to endure their chronic pain [or other continuing symptoms]." 107 The dissent believed this was not the intent of the California voters when they passed the Act. ${ }^{108}$

Justice Kennard would allow an employer to offer a "reasonable and effective form of accommodation." 109 The FEHA requires an employer to make reasonable accommodations for a "known physical or mental disability of an applicant or employee." 110 These provisions of the FEHA regarding reasonable accommodation "are to be construed liberally to accomplish each of its purposes."11 "The dissent disagreed with the majority in that "accepting an employee's physician-approved, off-duty marijuana use for medical treatment is not a reasonable accommodation

100. Id. at 209 (Kennard, J., dissenting).

101. Id.

102. Id. at 209-10.

103. Id at 211 .

104. Id. at 210 .

105. Id. at 211 .

106. Id.

107. Id.

108. Id.

109. Id. at 209.

110. Id. at 211 .

111. Id. at 211-12. 
because federal law prohibits marijuana possession." 112 The exact wording of the FEHA includes the "adjustment or modification of examinations, training materials or policies" as a reasonable accommodation. ${ }^{113}$ In applying these suggested accommodations to this case, Justice Kennard believed that the "modification of an employer's policy, such as a policy concerning employee drug use" would be reasonable. ${ }^{1 / 4}$ Justice Kennard rejected the proposition that something an employee does off duty that is illegal under federal law but permitted under state law can never be reasonably accommodated. ${ }^{115}$ The factors used to determine if an accommodation is reasonable consider "its benefits to the employee, the burdens it would impose on the employer and the other employees, and the availability of suitable and effective alternative forms of accommodation." 116 An employer can disregard the FEHA if it can show that the accommodation "would impose an undue hardship on the operation of its business."

Therefore, according to Justice Kennard in dissent, RagingWire would have to show that the employee's off-duty use of medical marijuana, which is illegal under federal law, would have an adverse effect on its business operations. ${ }^{118}$ RagingWire raised the argument that it may lose business opportunities with state agencies or with federal grants because of its inability to comply with drug-free workplace requirements imposed by state and federal law. ${ }^{19}$ Justice Kennard rejected this argument because the purpose of such laws were to "provide a drug-free workplace, which is defined as a site . . . at which employees of the entity are prohibited from engaging in the unlawful manufacture, distribution, dispensation, possession, or use of a controlled substance [such as marijuana]." However, Ross was not seeking to use marijuana at the workplace but at home as a medical treatment. ${ }^{121}$ Justice Kennard asserted that an employee's marijuana use at home and an employer's accommodation of employee's use will not interfere with an employer's drug-free workplace certification. $^{122}$

In Washburn v. Columbia Forest Products, Inc., the Oregon Supreme Court held that an employer does not have to accommodate an employee's

112. Id. at 212 .

113. Id.

114. Id.

115. Id.

116. Id.

117. Id.

118. Id. at 213 .

119. Id.

120. Id.

121. Id. at 204.

122. Id. at 213. 
medical marijuana use and that the particular illness from which the employee suffered did not constitute a disability under state law. ${ }^{123}$ In Washburn, an employee was terminated from his position after failing a drug test because of his use of medical marijuana to address the leg spasms that he suffered at night. ${ }^{124}$ The employer had a policy that prohibited employees from coming to work with alcohol or illegal drugs in their systems. ${ }^{125}$ The employee challenged his termination by alleging the employer discriminated against him based on his disability. ${ }^{126}$ The Oregon Supreme Court held that the employee was not disabled under Oregon law. ${ }^{127}$ Oregon Statutes 659A.100 to 659A.145, based on the provisions of the Americans with Disabilities Act, provide for the protection of disabled persons against employment discrimination and mandate reasonable accommodation by employers for such disabilities. ${ }^{128}$ The Oregon Supreme Court interpreted the state definition of disability as allowing for mitigating factors to counteract a disability. ${ }^{129}$ Because the employee was able to counteract the leg spasms with medication, the court held that the employee's impairment did not rise to the level of a disability as defined by the state's statute. ${ }^{130}$

A concurring opinion in Washburn relied on a different analysis to reach the same conclusion that the employee was not entitled to a reasonable accommodation. ${ }^{131}$ The concurrence stated that accommodation for medical marijuana use was not required because the federal Controlled Substances Act preempts state law with respect to reasonable accommodations. ${ }^{132}$ Even for medical purposes, "[ $\left.t\right]$ he Controlled Substances Act prohibits possessing, manufacturing, dispensing, and distributing marijuana." 133 According to the concurrence, the employee could not use the marijuana without possessing it, thereby violating federal law; therefore, this violation of federal law preempted state law requiring the employer to reasonably accommodate the employee's use. ${ }^{134}$

In Emerald Steel Fabricators v. Bureau of Labor and Industries, a temporary worker was hired as a drill press operator in a steel fabricating

123. Washburn v. Columbia Forest Products, Inc., 340 Or. 469, 478-80 (2006).

124. Id. at 472 .

125. Id. at $472-73$.

126. Id. at 472 .

127. Id. at $477-78$.

128. Id.

129. Id. at $479-80$.

130. Id.

131. Id. at 480-81 (Kistler, J., concurring).

132. Id. at 481 .

133. Id. at 481-82.

134. Id. 
business. ${ }^{135}$ When the worker was hired, he was told that at the end of a ninety-day period he would have to submit to a drug test before he could be eligible for permanent employment. ${ }^{136}$ The worker used marijuana one to three times per day for medical purposes; however, he never used marijuana on the job, his supervisor did not suspect the worker used marijuana, and the worker produced satisfactory work. ${ }^{137}$ As the ninety-day test date approached, the worker notified his supervisor that he was a medical marijuana user under Oregon law. ${ }^{138}$ The supervisor was unsure what effect that would have on the worker being offered permanent employment. One week after the worker notified his supervisor, the decision was made not to permanently hire the worker. ${ }^{139}$ The worker filed a complaint with the Bureau of Labor and Industries (BOLI) Civil Rights Division alleging the employer "(1) discharged [worker] because of his disability ... and (2) failed to reasonably accommodate [worker's] disability . ..."140 The employer asserted the following defenses:

[1] Oregon's Medical Marijuana Law does not require employers to accommodate the use of medical marijuana in the workplace or to accommodate off-duty use of medical marijuana in such a fashion that the employee would or could still be affected by such usage while on duty. [2] [Employer] is not required to accommodate medical marijuana users by permitting them to work in safetysensitive positions that would or could endanger the safety of themselves, co-workers or the public. [3] [Employer] is free to require that employees behave in conformance with the Federal Drug-Free Workplace Act of 1988. The protections of that Act do not apply to someone illegally using drugs, and marijuana is an illegal drug under Federal Law. [4] Oregon law prescribes that [Oregon's disability laws] be construed to the extent possible in a manner that is consistent with any similar provisions of the Federal Americans with Disabilities Act of 1990 . . . That Act does not permit the use of marijuana because marijuana is an illegal drug under Federal Law. ${ }^{141}$

135. Emerald Steel Fabricators, Inc. v. Bureau of Labor and Industries, 186 P.3d 300, 302 (Or. Ct. App. 2008), rev'd, 348 Or. 159 (2010).

136. Id.

137. Id.

138. Id.

139. Id. at 302-03.

140. Id at 303 .

141. Id. at 303-05 (citation omitted). 
The BOLI found that by firing the worker due to medical marijuana use, the "employer failed to reasonably accommodate [worker's] disability as required by Oregon statutes on unlawful discrimination against disabled persons." 142 The Oregon Court of Appeals affirmed the BOLI's decision due to inadequacies of the preservation of error for review. ${ }^{143}$ The result in Emerald Steel Fabricators clearly conflicted with the holding of the Oregon Supreme Court in Washburn, leading to the Oregon Supreme Court's reversal and reiteration of its holding in Washburn.

\section{B. Canadian Law}

The Canadian Human Rights Act contains Canada's discrimination laws. ${ }^{145}$ Under the Human Rights Act, disability is a prohibited ground of discrimination. ${ }^{146}$ "It is a discriminatory practice, directly or indirectly, (a) to refuse to employ or continue to employ any individual, or (b) in the course of employment, to differentiate adversely in relation to an employee, on a prohibited ground of discrimination." ${ }^{147}$ "It is a discriminatory practice for an employer ... (a) to establish or pursue a policy or practice... that deprives or tends to deprive an individual or class of individuals of any employment opportunities on a prohibited ground of discrimination." 148 An employer must accommodate an employee's disability to the point of undue hardship. ${ }^{149}$

In Geldreich v. Whisper Corwood, LP, Geldreich alleged employment discrimination against his employer, Whisper Corwood. ${ }^{150}$ The employer denied discrimination and moved to dismiss the complaint under the Human Rights Act. ${ }^{151}$ Geldreich worked as a Team Leader for the employer, which ran a saw mill and lumber yard. ${ }^{152}$ The employer fired Geldreich after multiple employees reported that Geldreich smoked marijuana at the mill. ${ }^{153}$ The employer had both a no-smoking policy and drug-free policy, of which the employer claimed Geldreich had

142. Id. at 301 .

143. Id. at 308 .

144. See generally Emerald Steel Fabricators, Inc. v. Bureau of Labor and Industries, 348 Or. 159 (2010).

145. See Canadian Human Rights Act, R.S.C. 1985, c. H-6.

146. Id.

147. Id.

148. Id.

149. Canadian human Rights Comm'n, Canadian human Rights Commission's POLICY ON ALCOHOL AND DRUG TESTING 2 (2009), available at http://www.chrcccdp.ca/pdf/padt_pdda_eng.pdf [hereinafter CHRC TESTING PoLICY].

150. Geldreich v. Whisper Corwood LP, 2009 BCHRT 178, para. 1 (Can. B.C.).

151. Id. para. 2.

152. Id. para. 4.

153. Id. para. 5. 
knowledge. ${ }^{154}$ The issue before the court was whether Geldreich "had either an actual or perceived mental disability which was a factor in the [employer's] decision to terminate him or whether his actual or perceived mental discrimination required accommodation in the workplace." 155 The court held that an obligation to accommodate "is not triggered by casual drug use against company policy. It is triggered when an employees [sic] is suffering from an addiction which requires accommodation or treatment." $" 156$

In Rio Tinto Alcan Primary Metal v. C.A.W.-Canada, Local 2301, the labor Arbitration Board held that an addiction to marijuana constituted a physical disability under Section 13 of the Canada Human Rights Code. ${ }^{157}$ An employee was terminated from his job at a smelting plant when he was caught smoking marijuana during his shift. ${ }^{158}$ At the time of termination, the employee had worked for the employer for thirty-four years and had a good overall work record. ${ }^{159}$ However, the employee did have a history of alcoholism and convictions for driving under the influence. ${ }^{160}$ The employee had gone to treatment for his alcoholism and had been sober for over fifteen years. ${ }^{161}$ By 2006, marijuana had taken the place of alcohol for the employee, and he was smoking daily. ${ }^{162}$ The employee's job with the employer was in a safety-sensitive position. ${ }^{163}$ The employer had a zero tolerance policy, which was communicated to all employees and provided for immediate termination for conduct of this nature.

The arbitration board member relied on the Human Rights Code in deciding upon the legitimacy of the employee's dismissal. ${ }^{165}$ The Human Rights Code is comparable to the Americans with Disabilities Act and provides that an employer cannot "refuse to continue to employ a person or discriminate against a person regarding employment . . . because of . . physical or mental disability."

After deciding that the marijuana addiction was a disability, the board member looked to see if the disability was a factor in the employee's

154. Id. para. 6 .

155. Id. para. 9.

156. Id. para. 14.

157. Rio Tinto Alcan Primary Metal v. C.A.W.-Canada, Local 2301 (2008), 180 L.A.C. 4th 1 (Can. B.C.).

158. Id paras. 2, 6 .

159. Id. para. 7 .

160. Id. paras. 7-11.

161. Id. para. 11.

162. Id. para. 10.

163. Id. para. 2.

164. Id. para. 12.

165. Id. paras. 69-75.

166. Id. para. 69. 
dismissal. ${ }^{167}$ The board member found that the addiction led to a lack of control on the employee's part, including an inability to make choices about when and where to smoke. ${ }^{168}$ This effect of the addiction was in part attributable to the employee's dismissal, despite the fact that the employer argued that the employee was dismissed because he was smoking in a safety-sensitive position and violated the zero tolerance policy. ${ }^{169}$ Additionally, the board member found that since the addiction qualified as a disability, the employer had to reasonably accommodate the disability to the point of undue hardship. ${ }^{170}$ Under these circumstances, the board member concluded that the employee's dismissal should be set aside. ${ }^{171}$ The board member noted that the employee had committed a serious misconduct, but that the addiction, which led to a loss of control, could be considered a mitigating factor in determining that the dismissal was inappropriate. ${ }^{172}$ To strike a balance between the seriousness of having and using drugs at a safety-sensitive workplace and the disability of the employee, the board member concluded the disciplinary action should be a lengthy suspension followed by reinstatement.

In North American Construction Group, Inc. v. Alberta, a prospective employee failed a mandatory pre-employment drug test after testing positive for marijuana. ${ }^{174}$ As a result of the failed test, the employee was not hired. ${ }^{175}$ The employee brought suit under Alberta's human rights laws. ${ }^{176}$ The employee was HIV-positive and smoked marijuana to relieve nausea. ${ }^{177}$ The employee sought a position as a heavy crane operator with the employer. ${ }^{178}$ The employee had an accident-free safety record. ${ }^{179}$ The employee argued that he was aware of the safety requirement of the position and that he would never smoke marijuana at the workplace. ${ }^{180}$ The employer refused to hire the employee due to the drug test results and further alleged that the employee was not up front about his medical

167. Id. paras. 95 106. A board member is the Canadian equivalent to an administrative law judge in the United States. See Labour Relations Code, R.S.B.C., ch. 244, part 8 (2004), available at http://www.lrb.bc.ca/code/\#part8.

168. Rio Tinto, 180 L.A.C. 4 th 1 , paras. $46-57$.

169. Id. paras. 96-98.

170. Id. paras. $95,105$.

171. Id. para. 102.

172. Id. para. 103.

173. Id. para. 104.

174. N. Am. Constr. Grp. Inc. v. Alberta, 2003 ABQB 755 (Can. Alta.)

175. Id. para. 2 .

176. Id.

177. Id.

178. Id.

179. Id.

180. Id. 
marijuana use. ${ }^{181}$ The court held that the acts of the employer warranted investigation and determination by a human rights panel on the legality of the employer's refusal to hire the employee. ${ }^{182}$ The court found that the complaint had merit "based on the clear evidence of the [employer's] hiring policy directives, i.e. drug-testing results as a conclusive determination of physical disability as a basis for denial of employment." 183

\section{Synopsis of American and Canadian Law}

The laws of Canada and the United States are similar regarding recreational use of marijuana. Both find that a lack of an addiction to marijuana precludes a finding of disability. ${ }^{184}$ Beyond this, the two countries' views diverge. The holding in Rio Tinto defines disability to include a current addiction to marijuana, even when marijuana is used at the workplace in a safety-sensitive position. ${ }^{185}$ The ADA is clear that a current addiction to an illegal substance does not constitute a disability. ${ }^{186}$ In continuation of the parallel views, Canada has required accommodation of medical marijuana use in the workplace, while California, which has the most liberal view on marijuana legalization in the United States, has held that state medical marijuana laws do not affect the definition of disability. ${ }^{187}$

\section{EFFECT OF MARIJUANA IN THE WORKPLACE}

Mixing medical marijuana use and the workplace is a dangerous combination, even if its use occurs outside of work. ${ }^{188}$ Public policy encourages drug-free workplaces, and an employer's tools to promote a drug-free work environment have increased dramatically over the last few decades. ${ }^{189}$ Additionally, even though state laws are becoming increasingly divergent from federal law with respect to medical marijuana, there are distinct federal benefits for employers who keep drugs out of the

181. Id.

182. Id. para. 8.

183. Id. para. 25.

184. 42 U.S.C. \$§ 12101-12117 (2010); Geldreich v. Whisper Corwood LP, 2009 BCHRT 178 (Can. B.C.).

185. Rio Tinto Alcan Primary Metal v. C.A.W.-Canada, Local 2301 (2008), 180 L.A.C. 4th 1 (Can. B.C.).

186. 42 U.S.C. $\S \S 12101-12117$.

187. Washburn v. Columbia Forest Products, Inc., 340 Or. 469 (2006); Ross v. RagingWire Telecommunications, Inc., 174 P.3d 200 (Cal. 2008); N. Am. Constr., 2003 ABQB 755 (Can.).

188. See infra note 23 and accompanying text.

189. See infra Part III.A. 
workplace. ${ }^{190}$ Requiring employers to accommodate an employee's use of medical marijuana complicates the drug-free workplace goal of an employer and compromises an employer's federal benefits.

\section{A. Drug-Free Workplaces: Public Policy}

There is a range of public policy reasons behind supporting drug-free workplaces, including the loss of government funding for projects, the correlation between a worker's impairment and absence and efficiency rates, employer liability due to acts of an impaired worker, and fiscal consequences suffered by the employer, employer's shareholders, employees, and customers. ${ }^{191}$ Employers adopt drug-free workplace policies to "improve work safety, to ensure quality production for customers, and to enhance [their] reputation in the community by showing that [they have] taken a visible stand against chemical abuse and the associated detrimental effects." ${ }^{192}$

Employers contracting with the federal government endanger profits and future contract opportunities if they fail to maintain workplaces that are not drug-free. ${ }^{193}$ Federal law requires employers to notify employees that the use of controlled substances, which includes marijuana, is prohibited. ${ }^{194}$ The federal government can terminate a particular grant and even impose five years of ineligibility from receiving future grants if an employer does not maintain a drug-free workplace. ${ }^{195}$

Employers not only stand to lose lucrative relationships at the federal level but also with states that invoke laws that criminalize the use of medical marijuana. ${ }^{196}$ For example, California requires all employers who receive state funding, regardless of the dollar amount of the contract or grant, to comply with California's Drug-Free Workplace Act of $1990 .{ }^{197}$ In exchange for the continuation of state grants, the Act requires an employer to: i) provide annual certification that controlled substances, including marijuana, are prohibited; ii) implement drug-free awareness programs that educate employees on the dangers of using drugs, educate employees on the consequences associated with drug use, and provide employees with access to drug counseling; and iii) make an employee's compliance with the

190. Id.

191. Deborah J. La Fetra, Medical Marijuana and the Limits of the Compassionate Use Act: Ross v. RagingWire Telecommunications, 12 CHAP. L. REV. 71, 73-74 (2008).

192. Id. at 74 (quoting Dolan v. Svitak, 527 N.W.2d 621, 626 (Neb. 1995)).

193. Id.

194. Id.

195. Id.

196. Id.

197. Id. 
program a condition of employment. ${ }^{198}$ The importance of such programs is reiterated through the associated penalties, which include delay of payment, contract or grant termination, a combination of both delay and termination, or ultimately debarment. ${ }^{199}$ These federal and state laws are not simply lip service; an employer's falsification of compliance can end in suspension or termination of the contract or grant and an employer's ultimate disbarment in the grant program. ${ }^{200}$

An employer's concern with maintaining a drug-free workplace goes beyond compliance with federal and state laws to encompass fears of the effect that marijuana has on an employee's performance. ${ }^{201}$

[Safety hazards are a reason to] be concerned from an occupational hazard standpoint .... [The employee using medical marijuana] could drop or mishandle or lose control of [merchandise or equipment] because of their impaired mind-altered judgment. The job would really need to require no judgment of any kind. No coordination, no technical judgment or no thinking skills in order to argue [medical marijuana] would be safe in the workplace. ${ }^{202}$

Studies show an invasive range of effects marijuana has on a person, even when used as medication, which support "[e]mployer fears of employee absenteeism, shiftlessness, or malfeasance while under the influence of marijuana." 203

While not discounting the potential benefits to patients and recommending further study, American Medical Association studies state that marijuana ingested for medicinal purposes may have the same biological sideeffects as marijuana ingested for recreational purposes. Marijuana increases the heart rate, and a person's blood pressure may decrease on standing. Marijuana intoxication can cause impairment of short-term memory, attention, motor skills, reaction time, and the organization and integration of complex information. Users may experience intensified senses, increased talkativeness, altered

198. Id.

199. Id.

200. Id. at 74-75.

201. Id. at 75. See also Tahman Bradley, Walmart Fires Cancer Patient with Prescription for Medical Marijuana, ABC NEws (Mar. 17, 2010), http://abcnews.go.com/ Business/michgan-man-fired-walmart-medical-marijuana/story?id=10122193.

202. Bradley, supra note 201.

203. Fetra, supra note 191, at 75. 
perceptions, and time distortion followed by drowsiness and lethargy. Heavy users may experience apathy, lowered motivation, and impaired cognitive performance. ${ }^{204}$

Whatever effects are experienced because of marijuana use, they become magnified in the work environment. ${ }^{205}$ The use of marijuana has been linked with 'increased absences, tardiness, accidents, workers' compensation claims, and job turnover." ${ }^{206}$ In the context of employee absenteeism, as a result of increased respiratory illnesses, "[p]eople who smoke marijuana frequently, but do not smoke[] tobacco, have more health problems and miss more days of work than nonsmokers."207 While at the job, the work performance and skills of an employee who uses marijuana become diminished. ${ }^{208}$ Illustrating this point, "[a] study among postal workers found that employees who tested positive for marijuana on a preemployment urine drug test had 55\% more industrial accidents, $85 \%$ more injuries, and a $75 \%$ increase in absenteeism compared with those who tested negative for marijuana use.

Additionally, the United States Department of Health and Human Services conducted a study comparing employees who had used marijuana within the past month and employees who had not. ${ }^{210}$ The study found that employees using marijuana were $7.9 \%$ more likely to have worked for three or more employers in the past year, $4.9 \%$ more likely to have missed two or more days in the past month due to illness or injury, and $8.6 \%$ more likely to have skipped one or more days of work over the past month. ${ }^{211}$ This study highlights the concerns regarding the duration of employment and attendance for employees who are currently using marijuana. ${ }^{2}$

Although many state medical marijuana laws expressly prohibit requirements that employers accommodate an employee's use of marijuana at work, some argue that an employer's duty to accommodate should extend to an employee's off-the-clock use. ${ }^{213}$ However, the effects of marijuana

204. Id. at 75 (quoting About AMA: Report 1 of the Council on Scientific Affairs (A-01) (2001), AM. MED. Assoc., http://www.ama-assn.org/ama/no-index/about-ama/13652.shtml (last visited Apr. 10, 2011) (citing PIERRI J. ChaIt, EFFECTS OF SMOKed MarijuANA ON Human Performance: a Critical Review, in Mariuuana/Cannabinoids: Neurobiology AND NeURophysiology 387-424 (A. Bartke \& L. Murphy eds., CRC Press 1992))).

205. Id.

206. Id. at 76 .

207. Id. at 75 .

208. Id. at $75-76$.

209. Id. at 76 .

210. Id.

211. Id.

212. Id.

213. Id. at 76-77. 
do not magically wear off once an employee clocks in. ${ }^{214}$ Marijuana has short-term and long-term effects. ${ }^{215}$ Prolonged exposure can result in respiratory illnesses, decreased cognitive ability, and up to six months of memory defects after the last usage. ${ }^{216}$

Another legitimate concern involves the extent of unknown liability employers face because of the actions of employees under the influence of marijuana. ${ }^{217}$ Employers are rarely held liable for an employee under the influence of alcohol or drugs when driving, operating heavy machinery, or engaging in other safety-sensitive tasks. ${ }^{218}$ However, courts have expanded the scope of employment, holding employers liable in order to compensate victims for wrongful acts of employees that are "bizarre and unforeseeable acts, or brutal, violent, and sexual crimes."219 "Forcing the employers to retain current drug users would close off one of the few methods that modern employers have left to insulate themselves from unlimited liability." 220 Employment decisions are business decisions. Thus, employers must retain the ability to make the decision that will foster and promote the overall health of their businesses. ${ }^{221}$

Driven by employer confusion and concern over what medical marijuana laws require employers to do when an employee uses medical marijuana, two identical bills were introduced in the Oregon House of Representatives in 2009. ${ }^{222}$ House Bills 2497 and 3052 sought to "clarify that employers are not required to accommodate medical marijuana in the workplace, regardless of where the use occurs. ${ }^{, 223}$ Oregon business and industry was represented at the House Business and Labor Committee

214. Id. at 77 .

215. Id. at $77-78$.

216. Id.

217. Id. at 79.

218. Id.

219. Id.

220. Id. at 79-80 (quoting Laura L. Hirschfeld, Legal Drugs? Not Without Legal Reform: The Impact of Drug Legalization on Employers Under Current Theories of Enterprise Liability, 7 CORNELL J.L. \& PUB. POL'Y 757, 840 (1998)).

221. See id. at 79-80.

222. Associated Oregon Industries, Business Groups Testify on Key Marijuana-Employee Bills, OR BUS. REP. (Mar. 25, 2009), http://oregonbusinessreport.com/2009/03/businessgroups-testify-on-key-marijuana-employee-bills/.

223. Associated Oregon Industries, supra note 222 (including testimony of Associated Oregon Industries, Oregon's largest business lobby; employment law attorneys; Western Partitions, a union contractor with up to one thousand employees; Oregon Self-Insurers Association, representing one hundred and thirty employers; Silverton Hospital; staffing companies such as The Stoller Group, which places over eighteen thousand employees with temporary employment each year; American Society of Safety Engineers, representing eight hundred occupational safety, health, and environmental professionals; and Serenity Lane, a private, not-for-profit treatment center for alcoholism and drug abuse). 
hearings on the bills. ${ }^{224}$ Business representatives reiterated their concerns regarding the requirement of employers to accommodate a Schedule I controlled substance, the increasing number of Oregon citizens holding licensure cards under the state's medical marijuana law, and the loss of federal funding and jobs if employers cannot certify compliance with the Drug-free Workplace Act. ${ }^{225}$

Specifically, a large union contractor addressed liability concerns with regard to a recent accident involving a medical marijuana user who used marijuana at lunch, returned to work and fell, resulting in a shattered leg. ${ }^{226}$ The employer spent more than five years and fifty thousand dollars accommodating the medical marijuana user, had trained the employee in fall protection, and yet was still liable for the fall. ${ }^{227}$ Safety issues infiltrate every workplace, and employers are craving clarity regarding their rights to maintain drug-free work environments. ${ }^{228}$

Organizations providing medical care are also not immune from the legal limbo. ${ }^{229}$ The Oregon Self-Insurers Association testified to a recent incident at a large health care facility in which a pharmacy technician who used medical marijuana caused frequent mistakes with patient medications. ${ }^{230}$ Oregon's Silverton Hospital prohibits "employees to work while using drugs or alcohol, including prescriptive narcotic medication in which the strength is known and the dosage specified." ${ }^{231}$ This policy highlights the fear over the lack of medical marijuana dosage recommendations and inconsistent strengths from plant to plant. ${ }^{232}$ Another source of apprehension stemming from the unique qualities and effects of marijuana is the potential abuse and dependency on the drug. ${ }^{233}$ In Oregon, there are currently no conditions for medical marijuana users to receive abuse and dependency evaluations. ${ }^{234}$

\section{B. Tools to Create and Maintain Drug-Free Workplaces}

Demonstrating the importance of having drug-free workplaces, U.S. employers have many tools to ensure an employee's compliance. ${ }^{235}$ These tools to help implement and enforce drug-free workplaces include drug

224. Id.
225. Id.
226. Id.
227. Id.
228. Id.
229. Id.
230. Id.
231. Id.
232. Id.
233. Id.
234. Id.
235. See infra Part III.B. 
policies, employee drug testing, and other resources from occupational safety and health administrations. ${ }^{236}$ Canada has a similar arsenal; however, a major difference exists in that Canadian employers have a limited ability to drug test employees. ${ }^{237}$

Similar to the structure of the ADA and state disability discrimination laws, the Occupational Safety and Health Act (OSHA) is a federal act, and each state enacts their own occupational safety and health laws. ${ }^{238}$ OSHA was passed in 1970 with the purpose of assuring

safe and healthful working conditions for working men and women; by authorizing enforcement of the [Act's] standards . . .; by assisting and encouraging the States in their efforts to assure safe and healthful working conditions; by providing for research, information, education, and training in ... occupational safety and health. ${ }^{239}$

The federal and state occupational safety and health laws support, and the federal and state governments sometimes even impose, responsibilities on employers to address substance abuse issues. ${ }^{240}$ The U.S. Department of Labor (DOL), which implements OSHA, encourages, supports, and provides employer resources to ensure drug-free workplaces. ${ }^{241}$ The DOL takes the position that drug-free policies at work "improve workplace safety and health in organizations of all sizes and in all industries.,242 Additionally, "[t]hey also play an important role in fostering safer and drugfree families, schools and communities across the [United States]."243 Specifically, the DOL encourages an employer's overall drug-free workplace program to include a drug-free workplace policy, supervisor training, employee education, employee assistance, and drug testing. ${ }^{244}$ An

236. See infra Part III.B

237. See CHRC TESTING PoliCY, supra note 149.

238. See 29 U.S.C. $\S 667$ (2004).

239. Occupational Safety and Health Act of 1970, 29 U.S.C. $\S \S 650-700$ (2004), available at http://www.osha.gov/pls/oshaweb/owadisp.show_document?p_table=OSHACT \&p_id $=2743$.

240. Office of the Assistant Secretary for Policy, Working Partners for an Alcohol- and Drug-Free Workplace: Frequently Asked Questions, U.S. DEP'T OF LABOR, $\mathrm{http} / /$ www.dol.gov/asp/programs/drugs/workingpartners/faq.asp\#ql (last visited Apr. 10, 2011) [hereinafter Working Partners FAQs]. See Fetra, supra note 191.

241. Office of the Assistant Secretary for Policy, Working Partners for an Alcohol-and Drug-Free Workplace: Drug-Free Workplace, U.S. DEP'T OF LABOR, http://www.dol.gov/ asp/programs/drugs/workingpartners/dfworkplace/dfwp.asp (last visited Apr. 10, 2011).

242. Id.

243. Id.

244. Id. 
employer's drug-free policy should be specific to the needs of each individual business and minimally address the purpose for the policy, include a description of prohibited behaviors, and discuss consequences for violation of the policy. ${ }^{245}$

The DOL does not regulate drug testing of employees. ${ }^{246}$ However, the DOL does recognize the strong policy behind drug-free workplaces and includes drug testing as a suggested element for an employer's drug-free workplace program. ${ }^{247}$ With respect to workplace drug testing, "[g]enerally, employers have a fair amount of latitude in handling drug testing as they see fit ... . However, there may be state laws that impact how drug testing is implemented." ${ }^{248}$ Some state laws go to the extreme of requiring employee drug testing in order for an employer to be awarded a contract. $^{249}$ Many U.S. employers utilize some form of drug testing in association with drug-free workplace policies, with "84[\%] of employers [requiring] pre-employment drug screening, 73 [\% requiring] reasonablesuspicion testing, 58[\% requiring] post-accident testing, and $39[\%$ requiring] random testing., 250

The Canadian Centre for Occupational Health and Safety (CCOHS) was developed in 1978 to be at the forefront for "work-related injury and illness prevention initiatives and occupational health and safety information." 251 One of the goals of CCOHS is to "provide[] Canadians with unbiased, relevant information and advice that supports responsible decision-making and promotes safe and healthy working environments. ${ }^{, 252}$ As opposed to the extent that the DOL provides information and resources to drug-free workplace programs as a whole, CCOHS mainly focuses on substance-abuse programs in the workplace. ${ }^{253}$ As a similar rationale to develop entirely drug-free workplaces, $\mathrm{CCOHS}$ recognizes that the impacts

245. Office of the Assistant Secretary for Policy, Working Partners for an Alcohol-and Drug-Free Workplace: Drug-Free Workplace Policy, U.S. DEP'T OF LABOR, $\mathrm{http} / /$ www.dol.gov/asp/programs/drugs/workingpartners/dfworkplace/policy.asp (last visited Apr. 10, 2011).

246. See Working Partners FAQs, supra note 240.

247. Id.

248. Id.

249. See OR. REv. STAT. ANN. $§ 279$ C.505(2) (West 2005) (requiring that "every public improvement contract . . . contain a condition that the contractor shall demonstrate that an employee drug testing program is in place").

250. Eve Tahmincioglu, Wal-Mart Worker Fired Over Medical Marijuana, MSNBC (Mar. 17, 2010, 2:44:13 PM EST), http://www.msnbc.msn.com/id/35913492/ns/businesscareers/ (discussing 2006 report from the Society for Human Resource Management).

251. CCOHS: About Forum, CAN. Centre for OCcupational Health and SafeTy, http://forum05.ccohs.ca/about.html (last visited Apr. 10, 2011).

252. Id.

253. OSH Answers: Health Promotion/Wellness/Psychosocial, CAN. CENTRE FOR OCCUPATIONAL HEALTH AND SAFETY, http://www.ccohs.ca/oshanswers/psychosocial/ (last visited Apr. 10, 2011). 
of substance abuse include "premature death/fatal accidents, injuries/accident rates, absenteeism/extra sick leave, and loss of production." 254 Components of a suggested substance abuse program include: statement of the purpose and objectives of the program; definition of substance abuse; statement of who is covered by the policy and/or program; statement of the employee's rights to confidentiality; that arrangements have been made for employee education; that arrangements have been made for training employees, supervisors, and others in identifying impaired [behavior] and substance abuse; provision for assisting chronic substance abusers; outline of how to deal with impaired workers; if necessary, statement of under what circumstances drug or alcohol testing will be conducted, and; provision for disciplinary actions. ${ }^{25}$

The allowance of employee drug testing in Canada is built upon a different legal structure than the hands-off approach of the United States, which leaves these decisions mostly up to the employer. ${ }^{256}$ In Canada, drug testing and an employer's decision based on those test results are governed by the Canadian Human Rights Commission (CHRC) and are heavily tied to discrimination laws. ${ }^{257}$ The CHRC recognizes that "[s]afety is important to employees and employers,"258 but strives to strike a balance so that "safety must be ensured in ways that do not discriminate against employees on the basis of a prohibited ground of discrimination."259

Consistent with the Human Rights Act, which prohibits "discrimination on the ground of real or perceived disability, drug ... testing [is] prima facie discriminatory." 260 The reasoning is "that a drug test cannot measure impairment at the time of the test, [and] requiring an employee or applicant for employment to undergo a drug test as a condition of employment may be considered a discriminatory practice on the ground of disability or perceived disability."261 In the case of marijuana use, the grounds for discrimination would be "the actual or perceived possibility that an individual may develop a drug or alcohol dependency in the future."262

Canadian law does make an exception to the general rule regarding drug testing and that relies on there being a "bona fide occupational

254. OSH Answers: Substance Abuse in the Workplace, CAN. CENTRE FOR OCCUPATIONAL HEALTH AND SAFETY, http://www.ccohs.ca/oshanswers/psychosocial/ substance.html (last visited Apr. 10, 2011).

255. Id.

256. See CHRC Testing Policy, supra note 149, at 2-4.

257. See id.

258. Id. at 2.

259. Id.

260. Id. at 3 .

261. Id.

262. Id. at $3-4$. 
requirement. ${ }^{, 263}$ Therefore,

[i]f testing is part of a broader program of medical assessment, monitoring and support, employers can test for drugs in any of the following situations: for "reasonable cause," where an employee reports for work in an unfit state and there is evidence of substance abuse; after a significant incident or accident has occurred and there is evidence that an employee's act or omission may have contributed to the incident or accident; or following treatment for drug abuse, or disclosure of a current drug dependency or abuse. ${ }^{264}$

However, pre-employment drug testing, as a general rule, is prohibited. ${ }^{265}$ A drug test is considered a medical examination and, therefore, is "limited to determining an individual's ability to perform the essential requirements of the job." 266 Under the Human Rights Act, a drug test does not reasonably gage if a worker will be impaired while working because a pre-employment drug test that has a positive result does not "predict whether the individual will be impaired at any time while on the job."267 Similarly, random drug testing does not help effectuate the goal that workers are not impaired while working because "a positive drug test [does not] measure present impairment and . . . only confirm[s] that a person has been exposed to drugs at some point in the past.",268

\section{Accommodation of Disabilities}

Putting aside the benefits and policy rationales behind requiring an employer to accommodate an employee's disability, employers must also develop and implement the accommodation for medical marijuana use, which in some cases may be very burdensome. ${ }^{269}$ An example of such a burden would be the accommodation of medical marijuana use and the complications it creates with the ADA and employer programs such as loss of funding, OSHA compliance, drug testing, and drug-free workplace policies. ${ }^{270}$

263. Id. at 5 .

264. Id.

265. Id. at 6-7.

266. Id. at 6.

267. Id.

268. Id. at 7.

269. See supra Part III.A.

270. Id. 
When an employee requires workplace accommodation, such considerations should be ad hoc and specific to the employee's limitation and needs. ${ }^{271}$

[A reasonable accommodation under the $\mathrm{ADA}$ ] may include: making existing facilities used by employees readily accessible to and usable by persons with disabilities; and job restructuring, part-time or modified work schedules, reassignment to a vacant position; acquisition or modification of equipment or devices, appropriate adjustment or modification of examinations, training materials or policies, the provision of qualified readers or interpreters, and other similar accommodations for individuals with disabilities. ${ }^{272}$

The Job Accommodation Network (JAN), working through the U.S. Department of Labor's Office of Disability Employment Policy, suggests the following questions to guide the development of employee accommodations:

1) What limitations is the employee ... experiencing?

2) How do these limitations affect the employee and the employee's job performance? 3) What specific job tasks are problematic as a result of these limitations? 4) What accommodations are available to reduce or eliminate these problems? Are all possible resources being used to determine possible accommodations? 5) Has the employee. . . been consulted regarding possible accommodations? 6) Once accommodations are in place, would it be useful to meet with the employee . . . to evaluate the effectiveness of the accommodations and to determine whether additional accommodations are needed? 7) Do supervisory personnel and employees need training regarding [the employee's disability]? ${ }^{273}$

Under the Canadian Human Rights Act, an employer's "duty to accommodate means the employer must implement whatever measures

271. Linda Carter Batiste, Accommodation and Compliance Series: Employees With Drug Addiction, JOB ACCOMMODATION NETwORK (Sept. 5, 2008), http://www.jan.wvu.edu/ media/drugadd.html\#Acc.

273. Batiste, supra note 271 . 
necessary to allow its employees to work to the best of their ability."274 Measures of accommodation include "eliminating or changing rules, policies, practices and [behaviors] that discriminate against persons ... [with disabilities]."275 When an employer develops an individualized accommodation for an employee, considerations include a "determin[ation of] what barriers might affect the person requesting accommodation; explor[ation of] options for removing those barriers; and accommodat[ion] to the point of undue hardship." 276 As with the ADA, Canadian discrimination laws require an employer to accommodate a disability up to undue hardship. ${ }^{277}$ An employer's duty to accommodate is excepted when:

a rule, standard or practice is based on a bona fide
occupational requirement . . [which] means that an
employer or service provider can only deny
accommodation if it does something in good faith for a
purpose connected to the job or service being offered, and
where changing that practice to accommodate someone
would cause undue hardship to the employer or service
provider, considering health, safety and cost.

With respect to health and safety, if an accommodation "would pose an undue risk to the health and safety of that person, or others, then an employer or service provider may be able to establish undue hardship." 279 In examining cost, undue hardship is not met just because "some cost, financial or otherwise, will be incurred ....,280 To reach undue hardship, the cost has to be "so high that it affects the very survival of the organization or business, or it threatens to change its essential nature,"281 and can be measured through such factors as "the size and financial resources of the employer, and external financing, and details of any additional risks or detriments.",282 Additionally, other factors to determine undue hardship include "the type of work performed, the size of the

274. Duty to Accommodate Fact Sheet, CAN. HUMAN RIGHTS Commission, http:/www.chrc-ccdp.ca/preventing_discrimination/duty_obligation-en.asp (last updated Oct. 06, 2010).

275. Overview of the Duty to Accommodate, CAN. HuMAN RIGHTS Commission, http:/www.chrc-ccdp.ca/preventing_discrimination/pagel-en.asp (last updated Aug. 23, 2004).

276. Id.

277. CHRC TESTING PoliCY, supra note 149, at 7-11.

278. Duty to Accommodate Fact Sheet, supra note 274.

279. Id.

280. Id.

281. Id

282. Id. 
workforce, the interchangeability of job duties, financial ability to accommodate, the impact on a collective agreement, and impact on employee morale." 283

There are examples in Canada of employers providing an area at work for medical marijuana users to use the drug. ${ }^{284}$ Although the dispute did not reach the level of a court order, two college professors used Canada's human rights laws to petition their employers, the University of Toronto and York University to accommodate their medical marijuana use. ${ }^{285}$ Even though it was a long battle for Professor Doug Hutchinson and Professor Brian MacLean, one year and three months respectively, their employers eventually conceded. ${ }^{286}$ Each professor qualifies to use medical marijuana under Canadian law. ${ }^{287}$ Now, each professor is provided a room in which they are allowed to smoke in while on the job. ${ }^{288}$ York University Professor Maclean argued that "[w] ithout the medication, [he was] disabled and ... not able to carry out meaningful and valuable, productive work."289 University of Toronto Professor Hutchinson likened a lack of accommodation to smoke at work with "kill[ing himself] - either literally or professionally." 290 In making its decision to accommodate the professor by providing him with a "smoking room," the University of Toronto hired a consultant to help best make the decision. ${ }^{291}$

The United States is not replete with examples of businesses accommodating the use of medical marijuana. ${ }^{292}$ Newbridge Securities, a Florida firm, accommodates the medical marijuana use of one of its brokers. ${ }^{293}$ Although Florida is not a medical marijuana state, the employee smokes legally as part of a test program through the U.S. government. ${ }^{294}$ It is possible that the employee could handle millions of dollars of his clients' money while under the influence, but this risk is taken with the knowledge of his clients and the support of his employer. ${ }^{295}$ While Newbridge

283. Preventing Discrimination, Can. Human Rights Commission, http://www.chrcccdp.ca/preventing_discrimination/page3-eng.aspx (last updated May 6, 2005).

284. See Natasha Elkington, Two Canada Professors Win Right to Toke Up at Work, REUTERS (Nov. 15, 2006, 5:34 AM EST), http://www.reuters.com/article/oddly EnoughNews/idUSN1431354020061115.

285. Elkington, supra note 284.

286. Id.

287. Id.

288. Id.

289. Id.

290. Intini, supra note 284 .

291. Id.

292. See Stephanie Armour, Employers Grapple with Medical Marijuana Use, USA TODAY (Apr. 18, 2007, 11:49 PM), http://www.usatoday.com/money/workplace/2007-0416-medical-marijuana-usat_N.htm.

293. Id.

294. Id.

295. Id. 
Securities accommodates the use of medical marijuana on the job, another option for employers would be to utilize flexible work schedules to accommodate medical marijuana use so as to decrease the likeliness of an employee being under the influence while on the clock. ${ }^{296}$

Many employers in the United States do not reach the stage of weighing the options for accommodation because employees are terminated if they test positive for marijuana. ${ }^{297}$ As its predecessor states have experienced, what protections an employee or employer has under Michigan's medical marijuana laws are under fire. ${ }^{298}$ Joseph Casias worked for Walmart for five years before being terminated for a positive post-accident drug test. ${ }^{299}$ Casias uses medical marijuana legally under Michigan law. ${ }^{300}$ Employers, including Walmart, are faced with diverging state and federal employment laws, as well as the real-life consequences of liability, such as negligence, if an employer is aware of an employee's marijuana use and a customer is injured as a result of the employee's error. ${ }^{301}$ Although medical marijuana supporters call Walmart's decision "uncompassionate," Walmart feels it is "unfortunate."302 Walmart is "sympathetic to Mr. Casias' condition. [However, as an employer, Walmart has] to consider the overall safety of [its] customers and associates, including [the patient], when making a difficult decision like this., 303

Many businesses are not accommodating employee medical marijuana use, and U.S. courts are increasingly backing this stance. ${ }^{304}$ Casias has not decided if he will go to court to contest his termination, but he has contacted the Michigan Department of Civil Rights, which will investigate the matter to determine if Walmart violated any disability discrimination laws. ${ }^{305}$ What happens in Michigan if this decision is challenged may further divide how medical marijuana laws are applied-this time across state lines. ${ }^{306}$ A direct conflict exists between

296. Id.

297. Id. See supra Part II.A. See also Tahmincioglu, supra note 250; Bradley, supra note 201.

298. See Tahmincioglu, supra note 250. See also Bradley, supra note 201.

299. See Tahmincioglu, supra note 250.

300. Id.

301. Id.

302. Id.

303. Id.

304. Id.

305. Id.

306. See Bradley, supra note 201. See also Troy Reimink, Wal-Mart's Firing of Employee for Using Medical Marijuana Incites Boycott, MICHIGAN LIVE LLC (Mar. 17, 2010, 7:18 AM), http://www.mlive.com/news/index.ssf/2010/03/wal-mart_fires battle_creek_em.html (discussing further consequences such as the call by marijuana 
Michigan's medical marijuana law, which provides protection against "disciplinary action by a business for medical marijuana use" and the Michigan employer's legal right to terminate employees after failing a drug test. ${ }^{307}$ Michigan attorney Michael Komorn believes society places a stigma on marijuana use that adversely affects even those who use it legally for medical purposes, and that "[i]n order to protect patients there has to be an evolution in thinking." 308

\section{RECOMMENDATION}

Current laws should be amended and new laws drafted to clarify that employers do not have to accommodate medical marijuana in the workplace. As it stands, employers within the United States do not know what to do regarding medical marijuana. ${ }^{309}$ They are in legal purgatory between federal and state law. ${ }^{310}$ Employers are unsure to what extent medical marijuana affects, or does not affect, their decisions regarding hiring, firing, liability and accommodation. ${ }^{311}$ Oregon employment lawyer Richard Meneghello succinctly describes the current reality of the employer stating, "[i]t's almost an untenable situation. Employers are screaming for answers. We know they [are] looking for clear answers, and there [is] not one out there right now. There [is] a lot of uncertainty. Employers are living in a dangerous situation." ${ }^{, 312}$ With the number of states legalizing medical marijuana increasing and other states with pending medical marijuana legislation, companies all over the country, whether in a medical marijuana state or not, are debating the employer's situation. ${ }^{313}$ The effects of marijuana use including absenteeism, malfeasance, and turn over ${ }^{314}$ may not be demonstrated by every medical marijuana user, but regardless, a stigma regarding marijuana use, medical or not, exists. ${ }^{31}$

The uncertainty of medical marijuana law may also be multiplied if states have differing laws regarding medical marijuana and employers. This issue is particularly prudent in areas where people live in one state but work in another. Theoretically, a similar problem may arise when an individual's place of residence and work location are separated by the U.S.Canadian border. However, due to the legal structure upon which each country's substantive laws are based, it makes more sense to reconcile

advocates to boycott Walmart and the holding of a rally in support of the terminated employee).

307. See Reimink, supra note 306.

308. Id.

309. See supra Part III.

310. Id.

311. Armour, supra note 292.

312. Id.

313. Id.

314. Fetra, supra note 191 , at 75 .

315. See Armour, supra note 292. 
diverging U.S. law than to blindly follow Canada's lead.

Times are changing: states are permitting medical marijuana; several states have pending medical marijuana legislation including traditionally conservative states; states are pushing further to legalize the recreational use of marijuana; and federal law, which prohibits any use of marijuana, has subsided in actively enforcing federal law against patients complying with state law. ${ }^{316}$ Although Canada's policy reflects the opposite stance of this Note, the uncertain effect medical marijuana has in the employment arena is uniform throughout the entire country. This situation requires current action from the federal and state governments of the United States to create a uniform application of the laws. ${ }^{317}$

\section{A. States Should Protect Employers' Rights}

States should protect an employer's right to enforce a drug-free workplace through a variety of measures, such as cautiously drafting medical marijuana acts, passing bills to amend existing acts to clarify that employers have no duty to accommodate medical marijuana use, and ensuring that courts continue interpreting medical marijuana laws with an eye toward decriminalization. ${ }^{318}$ When drafting medical marijuana legislation, the purpose of the law should be clearly stated and the law should be given proper scope and limitations. ${ }^{319}$ Additionally, states with pending medical marijuana legislation should review the language of existing acts and the past and current lawsuits regarding the acts when drafting new legislation.

The purpose of the California Compassionate Use Act is to exempt patients requiring medical marijuana treatment from "criminal prosecution or sanction." 320 The Oregon Medical Marijuana Act has a similar purpose to exempt such users from state criminal laws for possession. ${ }^{321}$ However, additional provisions of Oregon's law specifically refer to the requirements of employers. ${ }^{322}$ With regard to the application of the law to the workplace, the original language in the Oregon Medical Marijuana Act, ORS 475.300 to 475.346 , reads "[n]othing in ORS 475.300 to 475.346 shall be construed to require: . . . (2) An employer to accommodate the medical use of

316. See William M. Welchand \& Donna Leinwand, Slowly, States Are Lessening Limits on Marijuana, USA TODAY (Mar. 9, 2010, 11:25 AM), http://www.usatoday.com/ news/nation/2010-03-08-marijuana_N.htm.

317. See supra Parts I.B-C., II.

318. See infra Part IV.A.

319. See generally Cal. Health \& SAFETy Code ANN. § 11362.5 (West 1996); OR. Rev. STat. ANN. §§ 475.300, 475.346 (West 1999); Mich. Comp. LAws ANN. §§ 333.26424 333.26428 (West 2008).

320. Cal. Health \& Safety Code ANN. § 11362.5.

321. OR. REV. STAT. ANN. $\S \S 475.300-475.346$.

322. Id. 
marijuana in any workplace.",323 This provision is ambiguous in that it may only exempt an employer from accommodating the actual ingestion of marijuana in the workplace. Oregon State Representatives Bruce Hanna and Mike Schaufler introduced and sponsored identical bills in 2009 to remedy this ambiguity. ${ }^{324}$ Bills such as House Bill 2497 and House Bill 3052 sought to clarify the requirements of employers regarding accommodation of medical marijuana. ${ }^{325}$ The proposed bills would have amended Section 475.340 of the Act to read:

Nothing in ORS 475.300 to 475.346 shall be construed to: ... (2) Require an employer to: (a) Accommodate the medical use of marijuana in any workplace regardless of where the use occurs; (b) Allow an employee or independent contractor to possess, to consume or to be impaired by the use of marijuana during working hours; or (c) Allow any person who is impaired by the use of marijuana to remain in the workplace. (3) Preclude or restrict an employer from establishing or enforcing a policy to achieve or maintain a drug-free workforce. ${ }^{326}$

As gaps and ambiguities are found in current state medical marijuana laws, legislatures should take steps to amend their statutes in order to ameliorate the problems. ${ }^{327}$

In contrast, the purpose of the Michigan Medical Marihuana Act is to protect marijuana users from criminal penalty but also prevent them from being "denied any right or privilege, including ... disciplinary action by a business. ${ }^{328}$ This may appear to be a clearly stated purpose, but the statute also provides that employers are not required to accommodate medical marijuana use. ${ }^{329}$ Under Michigan's law, employers are not required to accommodate the use of "marihuana in any workplace or any employee working while under the influence of marihuana." 330 This potential conflict is exemplified by Walmart's recent firing of Joseph Casias. ${ }^{331}$ While an

323. Id.

324. H.B. 3052, 75th Gen. Assemb., Reg. Sess. (Or. 2009); H.B. 2497, 75th Gen. Assemb., Reg. Sess. (Or. 2009).

325. Associated Oregon Industries, supra note 222.

326. H.B. 3052, 75th Gen. Assemb., Reg. Sess. (Or. 2009); H.B. 2497, 75th Gen. Assemb., Reg. Sess. (Or. 2009).

327. See generally CAL. HeALTH \& SAFETY CODE ANN. $\$ 11362.5$ (West 1996); OR. REV. StaT. ANN. $\S \S 475.300-475.346$ (West 1999); Mich. CoMP. LaWs ANN. $\S \S 333.26424$ 333.26428 (West 2008).

328. Mich. COMP. LAWS ANN. $\S \S 333.26424-333.26428$ (West 2008).

329. Id.

330. Id.

331. See supra text accompanying notes $297-308$. 
employee may argue that medical marijuana was not used at the job, effects of marijuana use may linger both in the short- and long-term, resulting in the employee being under the influence while on the job. ${ }^{332}$

As states with pending legislation work toward final statutory language, they should adopt a clear purpose, like California and Oregon, which provide a compassionate solution for patients who were once forced to choose between medication and committing a criminal act. ${ }^{333}$ The purpose should not further compromise the health and safety of the patient or others by allowing marijuana, in any form, to waft into the workplace. ${ }^{334}$

State courts should continue to side with employers on these tough decisions. ${ }^{335}$ As the courts in California and Oregon have done, medical marijuana legislation should be interpreted consistently with their purpose, which is to decriminalize medical marijuana use. ${ }^{336}$ Courts have remained mindful of the federal classification of marijuana as a Schedule I drug. ${ }^{337}$ State laws decriminalizing medical marijuana have been upheld; however, courts have been less willing to allow medical marijuana laws to preempt federal disability laws, which are structured around the federal illegality of marijuana. ${ }^{338}$

It is one thing for state employment laws to differ by providing a greater degree of protection than federal law, but passing and upholding laws that are in direct conflict with federal law is another. ${ }^{339}$ The business setting minimizes the definition of state lines and the division of country and state. ${ }^{340}$ Profit from federal projects and losses from potential disability discrimination violations and civil suits are too high of stakes for the federal government to remain silent. ${ }^{341}$ The federal government has eased state fears of passing medical marijuana laws by taking a back seat to enforcement. ${ }^{342}$ Although the federal government is acquiescing to some degree, federal law clearly illegalizes any use of marijuana. ${ }^{343}$ Adding fuel

332. See supra Part III.A.

333. See generally supra Part I.B.

334. See supra Part III.

335. See Ross v. RagingWire Telecommunications, Inc., 174 P.3d 200, 202 (Cal. 2008); Washburn v. Columbia Forest Products, Inc., 340 Or. 469, 478-80 (2006); Tahmincioglu, supra note 250.

336. See Ross, 174 P.3d at 202; Washburn, 340 Or. at 478-80.

337. Ross, 174 P.3d at 202; Washburn, 340 Or. at 478-80.

338. See Washburn, 340 Or. at 481.

339. See id.; INTERNATIONAL LABOR AND EMPLOYMENT LAW, supra note 27, at 247-48.

340. See generally Fetra, supra note 191, at 74.

341. See supra Part III.

342. Feds: No More Arrests for Pot Smoking Patients, supra note 41.

343. Id. 
to the fire, laws from state to state diverge on these important issues. ${ }^{344}$ The time is now for the United States, at both federal and state levels, to enact uniform laws regarding the impact that medical marijuana may have in the employment sector.

Canada requires employers to accommodate the use of medical marijuana and recognizes a current addiction to and use of a drug such as marijuana as a disability that must be accommodated. ${ }^{345}$ Although United States law currently does not recognize an addiction to a drug accompanied by current use as a disability and should not require employers to accommodate the use of medical marijuana, the two countries' differing legal positions can be harmonized. ${ }^{346}$ As a matter of constitutionality, medical marijuana is legal in Canada. ${ }^{347}$ The United States is nowhere near that position; the U.S. Supreme Court has upheld the current classification of marijuana as a Schedule I drug and has permitted raids that enforce federal drug laws in medical marijuana states. ${ }^{348}$ Conversely, in Canada, the use of drug testing is a privacy issue and may be discrimination in and of itself; however, while not regulated by the U.S. government, drug testing is encouraged by both federal and state governments to ensure safe and healthy workplaces. ${ }^{349}$ Medical marijuana and drug-free workplace polices are on different legal footings in Canada and the United States. Although the outcomes differ, each country's laws consistently reflect the legal evolution that has played out in each country. Therefore, the United States should not wildly abandon all precedent that has supported decades of marijuana laws. Instead, the United States should seek to find its own balance in order to protect and support a bedrock of U.S. society-its employers.

\section{CONCLUSION}

Medical marijuana legislation is a compassionate solution to keep suffering patients from becoming criminals. ${ }^{350}$ However, states should enforce these laws with the intent to decriminalize medical marijuana without infringing upon an employer's duty to maintain healthy and safe

344. Compare CAL. Health \& SAFETY CODE ANN. $\$ 11362.5$ (West 1996), and OR. Rev. STAT. ANN. $\S \$ 475.300-475.346$ (West 1999), with Мich. COMP. LAWS ANN. $\S \S 333.26424$ 333.26428 (West 2008).

345. See supra Parts I.C, II.B.

346. Facts About the Americans with Disabilities Act, supra note 4.

347. See R. v. Parker, (2000) 49 O.R. 3d 481 (Can. Ont. C.A.).

348. See Gonzales v. Raich, 545 U.S. 1, 2 (2005).

349. See Working Partners FAQs, supra note 240; CHRC TESTING PoLICY, supra note 149 , at 2-4.

350. See Ross v. RagingWire Telecommunications, Inc., 174 P.3d 200, 202 (Cal. 2008); Washburn v. Columbia Forest Products, Inc., 340 Or. 469, 478-80 (2006). 
workplaces. ${ }^{351}$ States with pending legislation should review the language of current medical marijuana acts and carefully draft provisions regarding the act's purpose, limitation, and scope. ${ }^{352}$ Additionally, legislatures should review past and current case law, taking lessons from gaps or ambiguities in other state acts. ${ }^{353}$

States with current medical marijuana laws should take steps to amend their laws to clarify that employers are not required to accommodate an employee's use or influence of medical marijuana regardless of where such use occurs. ${ }^{354}$ Courts interpreting state medical marijuana laws should do so with the spirit of the intention of the laws-decriminalization. ${ }^{355}$ Differences from state to state regarding the effect medical marijuana laws have on employers and the legalization of medical marijuana will continue to pose conflicts as long as federal laws are contradictory to state laws. ${ }^{356}$ U.S. laws should not be patterned after Canadian laws simply because Canada is our neighbor. Each country's views of employer accommodation and disability discrimination laws rest on different foundations. ${ }^{357}$ Instead, the United States, including states with medical marijuana laws, should remain consistent with the current understanding of disability under the Americans with Disabilities Act. ${ }^{358}$ State medical marijuana acts do "not stand as a statutory trump card over every other statute and common law duty. Employers have a duty to their employees, customers, and the general public, to provide a safe and drug-free workplace." ${ }^{359}$ Therefore, employers should not be required to accommodate the use of medical marijuana by employees.

351. See supra Parts III, IV.

352. See supra Part IV.

353. Id.

354. Id.

355. Id.

356. Id.

357. Id.

358. Id.

359. Brief for Pacific Legal Foundation and National Federation of Independent Business as Amici Curiae Supporting Petitioner, Emerald Steel Fabricators, Inc. v. Bureau of Labor and Industries of the State of Oregon, 230 P.3d 518 (Or. 2010) (No. A130422). 